Est Ag 40 (2005) 65-97

\title{
La censura de los libros de Saturnino Calleja
}

Corría el año 1894. El mismo año en que se celebró el $4^{\circ}$ Congreso Católico, en Tarragona, al que habían precedido los de Madrid (1889), Zaragoza (1890) y Sevilla (1892). En ellos se había llevado a cabo una fuerte afirmación católica, con la pretensión de que sirvieran de punto de referencia y de vínculo de unión entre los católicos, frente a los ataques y acometidas que percibían desde el exterior, desde fuera de la Iglesia. Tan sólo habían transcurrido tres años desde la publicación, por parte de León XIII, de la encíclica Rerum novarum; pero la verdad es que no había tenido demasiada repercusión, y encontró escaso eco tanto en la jerarquía, como en los curas y en los seglares, más sensibilizados en la defensa de sus convicciones, y en cerrar filas compactas que en detectar un campo de acción al cual deberían haber sido especialmente sensibles.

Pero la afinidad con los temas no se improvisa, y los tiempos $-\mathrm{y}$ las personas que los viven - estaban más por la línea de construir barreras y erigir diques de contención frente a posibles ataques. Es cierto, y hay que reconocerlo en beneficio de las personas que vivieron esta época, que prácticamente se había pasado todo el siglo XIX en un constante tira y afloja entre conservadores y liberales. $Y$ en estos años de la regencia de María Cristiana, a la muerte de Alfonso XII, volvieron a aparecer las tensiones. Un ejemplo puede servir de referencia: mientras la enseñanza laica se había autorizado en 1881, en 1896 volvió a ser proscrita; dicho al revés, mientras la enseñanza religiosa había experimentado un ataque en 1881, en 1896 volvía a sentirse dueña de la situación, en exclusiva.

En el fondo, latía el problema de la aceptación de otros criterios religiosos, sociales y políticos, frente a la concepción monolítica, teñida de tintes patrióticos. Por cierto, que tales tonos patrióticos se derrumbaron en 1898 con la pérdida de Cuba y de Filipinas.

En este clima - diseñado a vuelapluma - tuvo lugar la intervención religiosa, o, si se prefiere decir de forma algo más cruda, intervino la censura eclesiástica a propósito de los libros de Saturnino Calleja, el mismo edi- 
tor al que el criterio popular hacía autor de innumerables cuentos infantiles.

Tal censura podría parecer una exageración inexplicable e intolerable, desde los criterios más moderados que hoy son comunes. Pero no estoy exagerando lo más mínimo. Por pura casualidad, mientras localizaba otros datos - como sucede con frecuencia - ha caído en mis manos una curiosísima censura, que, remitida desde el obispado de Madrid, se hizo llegar a otros puntos de España, a fin de darle la debida difusión, para que todo el mundo que pudiera tener acceso a ella supiera bien a qué ton quedarse respecto a las publicaciones de Saturnino Calleja. Éstas eran publicaciones pedagógicas, infantiles, instructivas. Y precisamente por ello llama aún más la atención semejante censura.

\section{Dejando hablar a los hechos}

Basta ya de introducciones, y, una vez situado el clima social y religioso envolvente, lo procedente es transcribir el decreto emanado del obispado de Madrid. Desearía que se leyera desde la serenidad, pero no encuentro modo de impedir que cada lector ponga la carga de asombro contenido, o de indignación vehemente ante la lectura de la larga exposición que sigue. Trataré, después de haberla transcrito, de explicarla, justificarla y hacerla entendible; pero mientras discurre el texto completo, no puedo hacer otra cosa más que llamar a la calma por parte del lector. Es evidente que, desde las posturas ideológicas de cada uno, la simple lectura puede ser ya un ejercicio de irritación, o de complicidad no disimulada con unos criterios caducos. El texto íntegro es:

Nos El DOCTOR Don José MARIA DE COS, por la gracia de Dios y de la Santa Sede Apostólica Arzobispo-Obispo de Madrid-Alcalá, Caballero Gran Cruz de Isabel la Católica, Senador del Reino, etc., etc.

Hacemos saber: Que el tribunal por Nos nombrado con fecha treinta de Setiembre próximo pasado y que se publicó en el Boletín de esta Diócesis del mismo día, para censurar los libros que al efecto Nos presentó el editor de esta Corte D. Saturnino Calleja, ha emitido dictamen del tenor siguiente:

"Excmo. y Rvdmo. Sr.: En cumplimiento del decreto fecha 30 de Setiembre del año pasado, con que $V$. E. tuvo a bien nombrarnos censores de doscientos sesenta y seis libros editados por D. Saturnino Calleja y sometidos por él mismo a la censura eclesiástica, desde luego 
procedimos a examinarlos con la debida atención, teniendo cada semana dos largas sesiones. Por ser tantos los libros nos los hemos ido repartiendo para informar como ponentes, llevando a la reunión de todos nosotros las observaciones que sobre el libro o algún pasaje o lámina suya se nos habían ocurrido a cada uno; con lo cual hemos imitado en lo posible la práctica que en esto siguen las Sagradas Congregaciones Romanas de la Inquisición y del Índice, al tenor de la Bula Sollicita et provida del sapientísimo Benedicto XIV. Pronto echamos de ver que convenía clasificar dichos libros en ocho grupos, según aparecen a continuación, y así los fuimos incluyendo en uno o en otro por juicio colectivo, en vista de las observaciones del ponente compulsadas en las páginas del libro y discutidas en la Junta cuanto era necesario.

Mas no contentándonos con este primer examen practicado ya con todos los libros, a fin de guiarnos respecto de ninguno por la ponencia de un solo censor, hemos repasado todo el trabajo hecho, tomándonos más tiempo y exigiendo que por lo menos tres censores hubieran leído y dieran testimonio positivo y concorde acerca de lo que no hubiese sido juzgado directamente por toda la Junta.

Resultado de todo ha sido presentar a V.E., como por acuerdo unánime tenemos la honra de presentarle, las ocho listas adjuntas con las calificaciones correspondientes. Pero antes debemos advertir: $1^{\circ}$. Que muchos de estos libros, juzgados ahora por nosotros, habian sido corregidos ya por encargo del editor Sr. Calleja, en cumplimiento de lo que el Gobierno eclesiástico de esta Diócesis decretó con fecha 7 de Agosto de 1893. - 20. Que por este motivo, y porque vemos que esta casa editorial de Madrid tiene una sucursal en la ciudad de Méjico, a fin de que los libros de ediciones anteriores no aparezcan autorizados o absueltos con la censura que ahora obtienen después de corregidos, creemos conveniente que V.E. haga pública esta declaración nuestra, y en particular, que se la comunique al Excmo. Sr. Arzobispo de Méjico, y que se haga lo que sea menester para que los libros censurados no se confundan con los que no lo fueron. - $3^{\circ}$. Que, interrogado por nosotros el editor D. Saturnino Calleja, ha declarado por escrito que si editó sin licencia eclesiástica Catecismos de la Doctrina cristiana y otras obras de religión, fue porque ignoraba la obligación de someter tales libros al examen y aprobación competente, obligación que promete cumplir en adelante con toda exactitud, según verá V.E. en su oficio de fecha 20 del mes corriente, que remitimos a V.E. junto con el que esta Junta le dirigió el día anterior. También promete el mismo oficio 
retirar, inutilizar o enmendar cuanto V.E. le ordene. - $4^{\circ}$. En vista de tan laudables declaraciones, y de conformidad con el espíritu benigno de la Santa Iglesia, somos de parecer que los libros de la lista segunda, pueden considerarse comprendidos en la primera; y los de la cuarta, en la tercera; y los de la sexta en la quinta; desde que se hagan en ellos las correcciones indicadas, y que por esto le sean comunicadas cuanto antes, aunque sea extraoficialmente, para que la tardanza no ocasione graves perjuicios a los intereses de su casa y a la subsistencia de los muchos operarios que de ella dependen, y que también se le facilite desde luego copias de las listas que no tienen censura adversa. Ahora, contrayendo la censura exclusivamente a lo que atañe al dogma o la moral, la formulamos informando:

$1^{\circ}$. Que los treinta y un libros comprendidos en la lista primera son recomendables y merecen la aprobación eclesiástica, como informados de espíritu cristiano, y que no tienen nada contrario al dogma y la moral.

$2^{\circ}$. Que los diez y ocho libros de la lista segunda merecerán igual aprobación, una vez que se hayan hecho las correcciones que van expresadas en ellos.

$3^{\circ}$. Que los sesenta y ocho de la lista tercera, podrán obtener también la aprobación eclesiástica, porque enseñan máximas de honestidad natural, u otros conocimientos útiles, sin contener nada reprobable.

$4^{o}$. Que los veinticuatro de la lista cuarta se hallarán en el mismo caso que los anteriores cuando se hagan las enmiendas anotadas en cada uno de ellos.

$5^{\circ}$. Que los cuarenta y uno de la lista quinta contienen lecturas de mero pasatiempo, sin moral cristiana ni natural, ni cosa contraria a la fe o a las buenas costumbres, ni mérito de aprobación positiva, por lo cual los dejamos con la fórmula de dimittuntur.

$6^{\circ}$. Que los quince de la lista sexta podrán sumarse a los de la anterior, así que se enmiende lo que en ellos se expresa.

$7^{\circ}$. Que los sesenta y tres de la lista séptima están plagados de encantamientos, hechicerías, transformaciones imposibles y enamoramientos, aunque no presentados en forma inmoral. Esta clase de libros ha sido objeto de particular atención. En las reglas del Índice "vetantur omnes libri et scripta necromantiae, geomantiae, hidromantiae, pyromantiae, honomantiae, chyromantiae, astrologiae 
judiciariae et omnia alia in quibus continentur sortilegia, beneficia ac auspicia; et contra haec legentes vel habentes procedi potest tanquam suspectos de haeresi". Los que ahora censuramos no recomiendan tales supersticiones ni las enseñan, ni semejantes encantamientos se presentan en forma que los haga algo creíbles, sino cual mero entretenimiento y con el rótulo de cuentos. Leer o retener tales frivolidades no es lo que la Sagrada Congregación del Índice considera motivo suficiente para que se tenga a cualquiera por sospechoso de herejía y se proceda contra él. El Pontífice Sixto V, en la Bula Cœli et terræ (1585) explica la arriba citada copiada regla de Índice de los que ejercen, enseñan o aprenden aquellas artes supersticiosas, y de los libros y escritos en que eso mismo se contiene; y en Roma no se condena un libro porque tenga tales cuentos de supernaturalismo fantástico, de lo cual nos hemos procurado y adquirido noticia cierta. Sin embargo, aun no aplicando a éstos de la lista sétima la gravísima censura de aquella regla del Índice, juzgamos que su lectura no hace bien a los niños, sino que debe calificarse de peligrosa para ellos, como puede serles perjudicial, por sembrar en la tierra virgen de sus nacientes inteligencias gérmenes de frivolidad y superstición, y por despertar prematuramente en sus tiernos corazones sentimientos y pasiones cuyo sueño se debe velar con toda la delicadez a y recato a que es acreedora la inocencia.

$8^{\circ}$. Finalmente que en los seis libros incluidos en la lista octava abundan las ideas y tendencias malsanas o pasajes lúbricos, que los constituyen libros malos, dignos de prohibirse y retirarse, conforme el editor ha prometido hacerlo.

Este es, excmo. e Ilmo. Sr., nuestro unánime parecer, que respetuosamente sometemos a la superior ilustración y autoridad de V.E., para que disponga lo que estime más conveniente. Dios guarde a V.E. Ilma. muchos años.

Madrid 25 de Enero de 1894.

Dr. José Fernández Montaña, Dr. Joaquín Torres Asensio, Dr. Fernández Tomás Ayuso, Dr. Manuel P. Pavía, Lic. Antonio Chacón y Muñoz, Anastasio García, Paulino Saja.

Excmo. y Rdmo. Sr. Arzobispo-Obispo de Madrid". 
En su consecuencia, y conformándonos en todo con el parecer de los censores, venimos en disponer y disponemos lo siguiente:

Primero: Aprobamos y recomendamos los libros de la lista primera, que son los siguientes: 1. Miguel y Ruiz, "La Buena Juanita".- 2. Calleja, "Los párvulos".- 3. Calleja, (colección de carteles), "Los párvulos".- 4. Fleury, "Catecismo histórico" (dos ediciones).- 5. Ripalda y Fleury.- 6. Astete, "Doctrina cristiana" (dos ediciones).- 7. Ripalda, "Doctrina cristiana" (dos ediciones).- 8. Fleury, "Diálogo de Historia Sagrada". - 9. Calleja, "Un libro para los niños".- 10. Sabatier, "Obligaciones del hombre".- 11. Escoiquiz, "Obligaciones del hombre".12. Fenelon, "El Padre nuestro".- 13. Calleja, "Urbanidad para niñas".- 14. Calleja, "Urbanidad para niños y niñas".- 15. Fernández, "Los deberes".- 16. Granada, "La oración del Padre nuestro".- 17. La niña caritativa, El legado de un padre.- 18. La madrastra.- 19. El pastor de las liebres.- 20. La flor marchita.- 21. El hijo obediente.-22. Fe, Esperanza y Caridad.- 23. En guerra con el mar.-24. La caja de cerillas.- 25. La conciencia.- 26. Blanca, la huerfanita.- 27. El caballero Bayardo.- 28. Rivadeneyra, "Vida de la Virgen".- 29. El camino del cielo. - 30. El bergantín.- 31. La Nochebuena.

Segundo: Aprobamos así mismo sin recomendación los de la lista tercera, que son los que siguen: 50. Jiménez Aroca, "Catón de los niños".- 51. Jiménez Aroca, "Silabario 10".- 52. Jiménez Aroca, "Silabario 2o".- 53. Jiménez Aroca, "Silabario 3"”.- 54. Jiménez Aroca, "Colección de carteles".- 55. Miguel Ruiz, "Catón de las niñas".- 56. Miguel Ruiz, "Silabario 1"..- 57. Miguel Ruiz, "Silabario

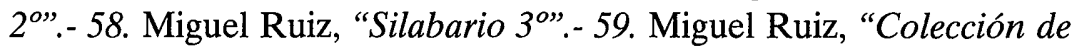
carteles".- 60. Fernández, "Cartilla para los niños".- 61. Seijas, "Catón metódico de los niños".- 62. Rodríguez Navas, "Narraciones históricas".- 63. Flórez González, "Lectura de manuscritos".- 64. Benito, "La música para los niños".- 65. Calleja, "Geografía" (dos ediciones).- 66. Gómez, "Gramática castellana”.- 67. Rodríguez Navas, "Gramática de la lengua castellana".- 68. Calleja, "El pensamiento infantil".- 69. Juez, "Lecciones de Aritmética".- 70. Fernández, "Definiciones de Aritmética".- 71. Gallego, "Aritmética para los niños".72. Fernández, "Geometría para los niños".- 73. Gómez, "Ortografía castellana".- 74. Calleja, "Nociones de higiene".- 75. Calleja, "Nociones de economía doméstica”.- 76. Chápuli, "El muestrario caligráfico".- 77. Ejercicio preliminar de lectura.- 78. La física al alcance de los niños.- 79. Geografía histórica.- 80. El mar y sus misterios.- 81. Geo- 
grafía astronómica.- 82. Reino vegetal.- 83. Reptiles y peces.- 84. El brujo y las tres hermanas. - 85. Pepito y Mariquita.- 86. No seáis mentirosos.- 87. El premio y el castigo.- 88. Jorge el valeroso.- 89. Roberto y Cecilia.- 90. El hombre en la luna.- 91. El espejo de Luisita.- 92. El gato perezoso.- 93. Las riquezas del sabio.- 94. La casa de Tócame Roque.- 95. Un rasgo de amor filial.- 96. La mentira más grande.- 97. La leyenda de la seda.- 98. La senda de la fortuna.- 99. El rey Tragabuches.- 100. El barril de aceitunas.- 101. El ciego por su culpa.- 102. El príncipe narigudo. - 103. El rey Midas. - 104. Al calor de una cerilla.105. Los dos gemelos. - 106. El lenguaje de las bestias.- 107. Dios en todas partes.- 108. Debemos estar agradecidos. - 109. La tía miserias.110. La flor del lino.- 111. El solitario.- 112. Los tres ciegos.-113. Las dos rocas. - 114. Una nariz prominente.- 115. Un viaje a la mesa.- 116. El ministro envidioso.- 117. El joven naturalista.

Tercero: Que ni aprobamos ni prohibimos, y sólo permitimos la lectura de los libros de la lista quinta, que son éstos: 142. El violón mágico.143. Los cabritos y el lobo.- 144. El doctor que todo lo sabe.- 145. Juana la lista.- 146. Lo que puede la astucia.- 147. Un amigo generoso.148. Los pájaros injuriados.- 149. Los músicos improvisados.- 150. Quién de los dos corre más. - 151. Los tres convidados.- 152. La cruz del diablo.- 153. Las agudezas de Juan.- 154. Viaje de Gulliver al país de los gigantes.- 155. Viaje de Gulliver al país de los enanos.- 156. La soledad y el olvido.-157. El jorobado.-158. La fortuna y la desgracia.159. Un banquete extraño.- 160. La fama del embustero.- 161. El castigo de un bribón.- 162. El gallo listo.- 163. Soñar despierto.- 164. El cantor del bosque.- 165. La caperucita roja.- 166. Aventuras del Barón de la Castaña.- 167. Las tres plumas.- 168. El flautista valiente.- 169. María Pez y María Oro.- 170. La joven hermosa novia.- 171. Aventuras de un náufrago.- 172. La gallinita y el pollito.- 173. Nobleza de un artesano.- 174. Justicia de Dios.- 175. Viajes en globo.- 176. La danza de las flores. - 177. El herrero jactancioso.- 178. El traje invisible.- 179. El gatito y las agujas.- 180. Un convite original.- 181. Las ranas mágicas. - 182. El fiel Juan.

Cuarto: Que mandamos corregir y devolvernos para su aprobación, luego que se hayan hecho las correcciones indicadas por los censores, los libros de las listas segunda, cuarta y sexta, que son los que a continuación se expresan: 


\section{LISTA SEGUNDA}

32. Jiménez Aroca, "Frases y cuentos".- 33. Jiménez Aroca, "Cuentos del abuelo".- 34. Torre y Marco, "Historia Sagrada".- 35. Loriquet, "Historia Sagrada".- 36. Tovar, "Educación cristiana de la juventud".37. El arte de ser feliz.- 38. La comadre muerta.- 39. La Religión Católica.- 40. El perdón de una culpa.- 41. Proteger a las golondrinas. - 42. Belleza y modestia.- 43. El tesoro engañoso.- 44. La herencia.- 45. La ingratitud.- 46. El médico ambicioso.- 47. La rana encantada.- 48. Santificar las fiestas. 49. El castigo merecido.

\section{LISTA CUARTA}

118. Rodríguez Navas, "Tratado de urbanidad”. - 119. González, "Catecismo de Agricultura".- 120. Parravicini, "Historia natural para niños".- 121. Peña, "Complemento de la educación escolar".- 122.Fernández, "Trozos literarios en prosa". - 123. Fernández, "Trozos literarios en verso".- 124. Calleja, "Historia de España".- 125. Parravicini, "Tesoro de las escuelas".- 126. Iriarte, "Fábulas literarias".- 127. Samaniego, "Fábulas en verso" (dos ediciones).- 128. Fernández y Ruiz, "La perla del hogar".- 129. Viaje alrededor del mundo.- 130. Historia de las bellas artes. - 131. Los tres reinos de la naturaleza.-132. La civilización y los grandes inventos. - 133. La medalla de la Virgen.- 134. El peral misterioso.- 135. Recuerdos históricos. 136. Las aves.- 137. Los mamíferos. - 138. La princesa fregona.- 139. La hermanita de los pobres. - 140. El ermitaño.- 141. El regalo de la hada.

\section{LISTA SEXTA}

183- El pulgarcito.- 184. La fuente de oro.- 185. Aquí no hay tal desgracia.- 186. El negrito y la pastora.- 187. Nicolasón y Nicolasillo.- 188. La reina de las hormigas. - 189. El caballo artificial.- 190. La mitología griega y romana.- 191. Cuentos de Fernandillo.- 192. El baúl maravilloso.- 193. El niño juez.- 194. El príncipe Balsora.- 195. El carbón de oro.- 196. El poder de la fortuna.- 197. Manuel.

Quinto: Creemos peligrosa para los niños la lectura de los libros contenidos en la lista sétima, y, por tanto, prohibimos su uso en las escuelas y colegios mientras no sean convenientemente reformados y aprobados por Nos, previa la oportuna censura. Sus nombres son éstos:

198. El ramito de nogal.- 199. Barba azul.- 200. Un joven afortunado.201. Un sueño largo.- 202. La hija del molinero.- 203. La princesa de Tonkin.- 204. La montaña de cristal.- 205. Rosita y Joaquinito.- 206. 
Los tres hermanos. - 207. La nevadita.- 208. La hermosa en el palacio encantado.- 209. La cenicienta.- 210. La montaña de imán.- 211. El palacio subterráneo.- 212. El príncipe mono.-213. La cierva encantada.- 214. Los perros negros.- 215. El médico y el rey.- 216. El castillo encantado.- 217. El pescador.- 218. El collar de diamantes. - 219. Blanca Nieves. - 220. El premio de Luisito.- 221. La princesa de los cabellos de oro.- 222. Rafaelito.- 223. Aventuras de dos niños.- 224. Las hijas del leñador.-225. La princesa Isabel.- 226. El enano encantador.- 227. La estatua prodigiosa.- 228. La fragua encantada.- 229. La almendrita.- 230. Los príncipes encantados. 231. El premio de la virtud.- 232. El alcázar de la dicha.- 233. Los sobresaltos de un sastre.- 234. Historia de un rey tuerto. - 235. La cabrita de oro.- 236. Las aventuras del feísimo Lentejilla.- 237. El viejo hechicero.- 238. El cantarito de lágrimas.- 239. El silbato prodigioso.- 240. El príncipe penitente.- 241. El diablo burlado. -242. La ramita de mejorana.- 243. El castigo de un ambicioso. - 244. Aventuras de Rogelio -245. La buena pesca.- 246. La vaca y el ternero.- 247. La estatua de mármol.- 248. La armadura misteriosa.- 249. Dos hermanas envidiosas. - 250. Un novio encantado. 251. La cola del gato.- 252. El oro del bosque.- 253. El caballero sin nombre.- 254. El castillo de cartón.- 255. Las tres hilanderas.- 256. La bola de oro.- 257. Un amigo de los niños. - 258. El anciano solitario.259. Un cuento chino.- 260. El premio de una buena acción.

Sexto: Prohibimos a todos los fieles de nuestra jurisdicción la lectura de los libros de la lista octava, y mandamos al editor susodicho, y a los libreros, maestros y particulares de nuestra Diócesis que en su poder tengan alguno o varios ejemplares de los mismos, los entreguen en nuestra Secretaría de Cámara y Gobierno por sí mismos, o por medio de sus Párrocos, haciéndoles saber, al efecto, que llevan los siguientes títulos:

261. Lo que está haciendo el diablo.- 262. El soldado listo.- 263. El príncipe y la ondina.- 264. Rafael.- 265. El príncipe Simplicio.- 266. El soldadito de plomo.

Séptimo: Mandamos que éste nuestro auto se comunique en debida forma al referido editor D. Saturnino Calleja, al Excmo. y Reverendísimo Sr. Arzobispo de Méjico y a todos los Reverendísimos Prelados de dentro y fuera de España que sobre este particular han tenido a bien preguntarnos, e insértese en nuestro Boletín Oficial para conocimiento del público. 
Dado en nuestro Palacio Episcopal de Madrid a doce de Marzo de mil ochocientos noventa y cuatro. JosÉ MARIA, Arzobispo-Obispo de Madrid-Alcalá.- Por mandado de S. E. I. el Arzobispo-Obispo, mi Señor, Dr. Julian De Diego y Alcolea, Arcediano Secretario.

\section{Al terminar el decreto}

Hasta aquí el largo texto, que inevitablemente era preciso reproducir, y que no podía ser resumido en una serie de explicaciones que hubieran ocupado más espacio que el propio decreto original. Tampoco valía la pena reproducirlo en parte, a medida que fuera apareciendo cada uno de los aspectos que saldrán en adelante, porque se perdería el hilo de la narración y del discurso original, así como su sabor auténtico.

Por descontado, no he introducido una sola línea que no fuera genuina, para no dar pie a interpretaciones mías como si fueran primitivas, así como para evitar subjetivismos con los que yo pudiera tratar de canalizar la opinión ajena. Lo único que he hecho ha sido introducir letra cursiva, a fin de dejar más clara la redacción primitiva y distinguirla de mis anotaciones. Con eso, lo único pretendido es evitar cualquier tipo de confusiones.

$\mathrm{Y}$ si yo he procedido con honestidad, quisiera que quienes leyeran estas páginas procedieran de la misma forma y evitaran comentarios sesgados a media lectura, así como apresuradas condenas o expresiones más o menos sinceras de repulsa y rechazo del oscurantismo de la Iglesia. No es posible olvidar que estamos a un siglo de distancia de los hechos, y que desde entonces han cambiado mucho las cosas y ha llovido mucho.

\section{Para una mejor comprensión}

Lo ideal sería saber cuál ha sido el factor que originó todo este proceso, para poder comprender lo más exactamente posible qué ha sucedido y por qué han sucedido las cosas de esta forma. En otras palabras, ¿por qué en ese momento preciso (30 de septiembre de 1893) el obispo de Madrid tomó la decisión de encomendar a una comisión diocesana la tarea de proceder a la revisión minuciosa del fondo editorial de Saturnino Calleja?

No consigo saber la razón precisa, ni desentrañar la incógnita. Podría tratarse de una labor rutinaria, que se hubiera emprendido además con otras editoriales, y cuyo contenido no hubiera trascendido por no haberse publicado, por no tener la notoriedad de la editorial Calleja, o porque no encontraron nada digno de consideración. También cabría que, como con- 
secuencia de la lectura — fortuita o no- de alguna obra editada por Calleja, alguien se hubiera alarmado ante ciertas palabras o criterios, y hubiera llamado la atención de alguna persona calificada, responsable; lo cual hubiera dado origen al proceso.

De no ser así, no encuentro una razón peculiar por la cual valiera la pena llevar a cabo una investigación sobre los fondos editados por Casa Calleja, como si fueran sospechosos de estar difundiendo de forma habitual y permanente una doctrina errónea. Nada de cierto puede haber en esta posibilidad, que debe quedar descartada de plano.

Sólo queda la hipótesis verosímil de una inspección rutinaria, o la peculiar alarma sugerida por algún título concreto, que diera pie a la revisión de todo el fondo editorial.

\section{La voluntad de Saturnino Calleja}

Sea cual fuere la razón que decidiera la intervención de la censura madrileña, en el decreto precedente aparece explícita, clara y diligente la voluntad del editor Saturnino Calleja de que se procediera a la revisión de sus libros"1. Las frases no dejan lugar a dudas: “...censurar los libros que al efecto Nos presentó el editor de esta Corte D. Saturnino Calleja”; “...doscientos sesenta y seis libros editados por D. Saturnino Calleja y sometidos por él mismo a la censura eclesiástica"; "Que muchos de estos libros, juzga" dos ahora por nosotros, habian sido corregidos ya por encargo del editor $S r$. Calleja, en cumplimiento de lo que el Gobierno eclesiástico de esta Diócesis

\footnotetext{
1 Saturnino Calleja Fernández (Quintanadueñas [Burgos] 1855 - Madrid 1915) estuvo siempre interesado por la elevación del nivel cultural de la sociedad, especialmente de los niños, por medio del desarrollo de la lectura. A ello contribuyó personalmente, con la fundación, ya en Madrid, de la Editorial que lleva su nombre, el año 1876. (Algunos afirman que esto sucedió el año anterior, a pesar de la constancia expresa en libros de su propia editorial). Entre su fondo editorial fueron apareciendo libros formativos, que podrían servir, en principio, para todas las edades, además de numerosos libros de tipo escolar, o de entretenimiento, destinados a los niños. También estuvo interesado en la dignificación de la profesión de libreros, que se plasmó en la fundación de la Asociación de la Librería de España. Igualmente convocó una Asamblea Nacional de Maestros, en 1891. En torno a la persona y obra de Calleja, pueden consultarse: $H$. Escolar, La edición moderna: siglos $X I X$ y $X X$, Madrid, Fundación Germán Sánchez Ruipérez, 1996; J. GARCIA PADRINO, Tradición e innovación en la narrativa infantil, en VARIos, Estudios de Filología y su Didáctica, v. II, Madrid, Publicaciones Pablo Montesinos - Departamento de Filología y su Didáctica, 1992; E. Calvo, Un bosque de cuentos. Evolución del género infantil, Minotauro Digital, julio 1999; J. RUIZ BERRIO (dir.), La Editorial Calleja, un agente de modernización educativa en la Restauración, Madrid, UNED Ediciones, s.a.
} 
decretó con fecha 7 de Agosto de 1893"; "También promete el mismo oficio retirar, inutilizar o enmendar cuanto V.E. le ordene"; "[solicita]... le sean comunicadas cuanto antes, aunque sea extraoficialmente, para que la tardanza no ocasione graves perjuicios a los intereses de su casa y a la subsistencia de los muchos operarios que de ella dependen, y que también se le facilite desde luego copias de las listas que no tienen censura adversa".

El mismo Saturnino Calleja tuvo la iniciativa de presentar los libros editados por él. E incluso se habla de una intervención anterior, de fecha 7 de agosto de 1893, con arreglo a la cual, bastantes libros ya habían sido corregidos por el editor. Esto supone, pues, dos actuaciones diversas por parte del obispado madrileño. Una primera, el 7 de agosto de 1893, que se resuelve en la modificación por parte de Saturnino Calleja de bastantes de sus libros, aunque resulte imposible saber qué libros fueron corregidos y en qué sentido; la única indicación es que son muchos de los libros de la lista a que se refiere la segunda intervención. Y precisamente porque habían sido ya retocados no son objeto de otra reforma (aunque sí de revisión y examen). La segunda intervención tiene su arranque casi dos meses después, exactamente el 30 de septiembre de 1893, con el decreto del obispo de Madrid, José María de Cos, quien nombra la comisión al efecto para que proceda al examen del fondo editorial de Calleja.

Si Calleja ha puesto espontáneamente los libros a disposición de los censores (266 libros) el 30 de septiembre, no se entiende muy bien que el 7 de agosto hubiera entregado una parte de esos libros, pero se hubiera reservado otra parte. Y si el 7 de agosto ha sometido a examen los 266, tampoco se entiende muy bien que haya corregido "muchos de estos libros" pero no todos. En caso de que no los hubiera corregido, o también en la suposición de que no hubiera presentado su fondo editorial completo, se entiende lógica la segunda intervención de los censores. Sin embargo, los datos parecen hablar en sentido contrario, al afirmar que la voluntad de Calleja es que "también promete el mismo oficio [de Calleja] retirar, inutilizar o enmendar cuanto V.E. le ordene". Unos ya han sido rectificados, y promete hacer lo mismo con el resto, a resultas de lo que establezca la comisión nombrada al efecto. No parece, pues, que se pueda acusar a Calleja de voluntad de entorpecer la revisión o de ocultar datos o libros. Más bien, todo lo contrario.

La única súplica (o condición) que Saturnino Calleja establece es que se le comunique el resultado lo antes posible, a fin de no salir perjudicado en la venta, porque se pondría en entredicho toda la empresa editorial, con la consiguiente pérdida de crédito personal, así como la de los empleados a su cargo. Y pretende evitar tanto el desprestigio como el quebranto econó- 
mico. Su petición es razonable. No se niega a introducir modificaciones, sino a que, en caso de tener que hacerlo, esto no afecte a la rentabilidad de la editorial.

¿La iniciativa de revisión arranca de Calleja?; ¿se vio presionado por alguna circunstancia particular que se nos escapa?; ¿pudo parecerle mejor adelantarse a los acontecimientos, en lugar de lamentarlos después? No hay forma de saberlo. La voluntad de evitar las pérdidas económicas rige sus actuaciones como empresario. Y es lógica. La decidida intención de Calleja de poner sus talentos y medios al servicio de la educación de la infancia, parece que está fuera de toda cuestión, porque si hay algo que subyace a su enorme esfuerzo editorial ha sido precisamente el suministrar a los niños y educadores una literatura claramente educativa. ¿Pudo haberse movido Calleja, además, con un convencimiento religioso personal? Desconozco este dato, y no soy capaz de afirmarlo ni de negarlo.

Es evidente que Calleja editó múltiples obras de signo religioso entre ellas algunos catecismos-, así como es patente que en las obras educativas en general, había un sentido religioso implícito y subyacente en múltiples ocasiones, y explícito en numerosísimos pasajes de algunas obras y en algunas obras completas. En el ambiente escindido que primó en el siglo XIX - fundó la editorial en 1876- si él hubiera sido de talante liberal, no hubiera dejado de tener oportunidades de manifestarlo. Y habría encontrado apoyos ideológicos, partidistas y pedagógicos en un sector de la sociedad. Precisamente el mismo año de 1876 comenzó su andadura la Institución Libre de Enseñanza, con un ideario educativo al margen de lo religioso. Es patente que hubiera encontrado en ella apoyo y aliento si hubiera seguido un derrotero similar al de la Institución. De no haberlo hecho, y a la vista de las innumerables referencias religiosas en las obras editadas por él, parece lógico deducir que se trataba de una persona de convencimientos religiosos personales. Lo cual le impulsó a presentar de modo espontáneo los 266 libros a la censura madrileña.

\section{La censura de los catecismos en particular}

Entre los libros examinados, hay varios catecismos. Concretamente, los de Astete, Ripalda y Fleury; junto a ellos hay tres historias sagradas: las versiones de Fleury, de Torres y Marco, y de Loriquet. En la comunicación que Saturnino Calleja dirige a la comisión examinadora, como consecuencia de las interrogaciones que tal comisión le expresó de forma directa el 19 de enero de 1894, Calleja respondió al día siguiente, 20 de enero, sin 
dolo: "interrogado por nosotros el editor D. Saturnino Calleja, ha declarado por escrito que si editó sin licencia eclesiástica Catecismos de la Doctrina cristiana y otras obras de religión, fue porque ignoraba la obligación de someter tales libros al examen y aprobación competente, obligación que promete cumplir en adelante con toda exactitud, según verá V.E. en su oficio de fecha 20 del mes corriente, que remitimos a V.E. junto con el que esta Junta le dirigió el día anterior".

La normativa canónica establecía que los libros que sirvieran para la educación de la fe, como es el caso de los catecismos, así como las obras teológicas, o las versiones de la biblia, hubieran de ser sometidas a aprobación eclesiástica ${ }^{2}$. Saturnino Calleja actuó desde otros presupuestos absolutamente normales: la conciencia de estar editando unos textos tradicionales, suficientemente contrastados y vistos como para tener necesidad de ser sometidos de nuevo a revisión. Y en consecuencia, Calleja procedió con absoluta tranquilidad, publicando unas obras que no le ofrecían ningún tipo de duda. Otra cosa distinta es que los tres catecismos en particular a que se refiere y por los que pregunta la comisión investigadora, habían sido sometidos a toda clase de alteraciones por parte de autores y editores bienintencionados, quienes no habían respetado ni la integridad literaria, ni la doctrina presentada; como consecuencia, ya no eran los genuinos textos de Astete, Ripalda ni Fleury, aunque sus nombres siguieran apareciendo en las cubiertas respectivas. Calleja desconocía estos datos, y, con el convencimiento con que procedieron todos sus contemporáneos, tenía la certeza de estar editando los catecismos tradicionales, que no suponían más problema que el de llevar a cabo nuevas ediciones que siguieran a las muchas que les habían precedido.

No deja de ser llamativo el interés de la comisión censora, que dedica un párrafo especial a estos textos de religión, separándolos del resto de los libros examinados. Las ediciones de Astete y Ripalda habían sido anteriormente depuradas. Otro tanto le había ocurrido al catecismo de Fleury, y,

${ }^{2}$ La norma arrancaba de lo dispuesto por el concilio de Trento, sesión IV, De scriptura et traditione, en el decreto segundo, que se refiere a la aprobación de ediciones de la biblia y otros libros religiosos. Dicho decreto dice: "[Sancta Synodus] decernit et statuit (...) nullique liceat imprimere vel imprimi facere quovis libros de rebus sacris sine nomine auctoris, neque illos in futurum vendere aut etiam apud se retinere, nisi primum examinati probatique fuerint $\mathrm{ab}$ ordinario, sub poena anathematis et pecuniae in canone concilii novissimi Lateranensis apposita" (= El concilio manda y establece [...] que a nadie le es lícito ni imprimir ni hacer imprimir cualquier clase de libros sagrados sin que conste el nombre del autor, ni tampoco venderlos más adelante o guardarlos para sí, sin que antes hayan sido examinados y aprobados por el ordinario, bajo pena de condenación y de la multa establecida en el último concilio de Letrán). 
como consecuencia, la historia sagrada puesta a nombre de Fleury. Esto no fue obstáculo para que la atención se fijara de manera destacada en estas obras. No tengo referencias de las otras dos historias sagradas, las de Torres y Marco y de Loriquet. Me figuro que no tendrían una preocupación diversa de la que manifestaron los censores para el resto de las obras religiosas. Pero así como en las demás obras no me consta una intervención específica de la comisión sobre el contenido del catecismo, sí me consta de forma expresa su actuación sobre el Catecismo histórico de Fleury. Éste sufrió alguna modificación, que fue avalada —como garantía- por los miembros de la comisión, a fin de que Calleja pudiera seguir editándola con tranquilidad ${ }^{3}$.

\section{Las razones de los censores}

En su razonamiento expositivo, los censores no actúan de manera arbitraria, sino que exponen los motivos en que se fundamentan: Siguen las normas y decisión del Arzobispo de Madrid, quien ha creado la comisión al efecto; por otra parte actúan acordes con las reglas contenidas en el Índice expurgatorio de libros prohibidos; más en concreto, actúan de conformidad con la regla XI, cuya referencia omiten, pero que citan expresamente en latín, según la cual "vetantur omnes libri et scripta necromantiae, geomantiae, hidromantiae, pyromantiae, honomantiae, chyromantiae, astrologiae judiciariae et omnia alia in quibus continentur sortilegia, beneficia ac auspicia; et contra haec legentes vel habentes procedi potest tan-

\footnotetext{
3 En varias ediciones de Calleja, diversas entre sí, y sin fecha, como solía ser frecuente en las obras publicadas por esta editorial, aparece la siguiente portada: "Catecismo histórico por el abate Claudio Fleury. Edición corregida por siete teólogos presididos por un Ministro del Tribunal de la Rota, nombrada expresamente para corregir las obras de la CASA CALLEJA por el Exmo. e Ilmo. Sr. Arzobispo-Obispo de Madrid-Alcalá con fecha 30 de septiembre de 1893". Hay alguna ligera variente en la redacción de esta nota entre unas ediciones y otras. La redacción anterior corresponde a la que podría ser la edición más cercana a los hechos; carece de fecha, y está editada por la sucursal de Calleja en México. Levemente modificada consta en otras seis ediciones diversas más, de las cuales una tiene la fecha de 1897 (también editada en México) y otra la de 1898 (editada en Madrid); las demás no tienen fecha. Además, la edición fechada en 1898 incluye en la vuelta de cubierta la siguiente nota: "Fleury.Catecismo histórico. Esta obra, que está traducida del francés, que lleva sirviendo de texto en las escuelas más de siglo y medio, y que ha sido reproducida por cientos de editores, ha llegado a contener errores que son herejías. La presente edición, propiedad exclusiva de esta casa, está cuidadosamente revisada y corregida por siete teólogos nombrados por el Ilmo. Sr. Obispo de Madrid Alcalá, con fecha 30 de Septiembre de 1894; del Fleury no creemos que haya ninguna más limpia de errores que la presente. Pedir siempre edición Calleja, la cual es propiedad de su editor". Muy similar es la nota explicativa de la vuelta de contracubierta, en las edición de México, s.a., y Madrid, s.a.
} 
quam suspectos de haeresi" (= se prohíben todos los libros y escritos de nigromancia, piromancia, onomancia, quiromancia, astrología judiciaria ${ }^{4}, \mathrm{y}$ todos aquellos en que se incluyen sortilegios, beneficios [¿equivalente a promesas?] $\mathrm{u}$ auspicios; $\mathrm{y}$ se ha de proceder contra los que leen o poseen estos escritos como sospechosos de herejía).

Además, citan la bula Coeli et terrae, de Sixto V, datada en 1585; la bula Sollicita et provida de Benedicto XIV; y la forma práctica de actuar de las Congregaciones romanas del Índice y de la Inquisición.

Dicho de otra forma, no se trata de una comisión de indocumentados o carentes de experiencia que se ponen a juzgar a la ligera. Son personas formadas, los textos los denominan "teólogos", bajo la presidencia de un "Ministro del tribunal de la Rota". Lógicamente tal presidente es el que firma el informe en primer lugar, su presidente, de nombre José Fernández Montaña.

Son conscientes de que su decisión puede tener un alcance notable, tanto en Madrid, de donde arranca todo el asunto, como también en el resto de España, por la difusión lograda por los impresos de Calleja; y también en México, por la editora sucursal, regentada por "Herrero Hermanos", como aparece impreso en los libros que procedían del otro lado del Atlántico. Y de ahí la recomendación, al entregar su informe, para que éste, o la posterior decisión que pueda tomar el obispo de Madrid-Alcalá se haga llegar a todos los lugares a los que irradiara la influencia de la editorial en cuestión.

No es posible considerar a los miembros de esta comisión como personas arbitrarias, que procedieran por impulsos poco controlados, o por pura manía persecutoria. Aunque no deja de resultar irónico imaginarse a unos sesudos teólogos realizando su labor investigadora sobre unos cuentecillos destinados a la lectura de la chiquillería. Parece que resulta más lógico imaginarlos enfrascados en libros de más altos vuelos y sobre materias más serias y trascendentales.

\section{Clasificación de las obras examinadas en grupos}

La forma de proceder de la comisión les llevó a tomar la decisión de distribuir el trabajo entre sus miembros, puesto que 266 libros, aunque

\footnotetext{
4 Equivale a los que hoy se denominan horóscopos, por la descripción que hace el Indice de libros prohibidos.
} 
todos no fuesen de gran formato, suponía una labor extensa. El reparto entre los miembros de la comisión llevó a que los que suscitaron alguna sospecha fueran revisados y leídos por tres personas distintas, a fin de hacer un juicio valorativo lo más equilibrado posible.

Consecuencia de esta labor fue la clasificación de las obras en ocho grupos diversos, con sus respectivas calificaciones, según las afinidades de los libros que los integraban; la clasificación entregada en su informe es ésta:

LISTA PRIMERA: aprobados y recomendados.

LISTA SEGUNDA: aprobados y recomendados; deben corregirse.

LISTA TERCERA: aprobados sin recomendación.

LISTA CUARTA: aprobados sin recomendación; deben corregirse.

LISTA QUINTA: ni aprobados ni prohibidos; sólo permitidos.

LISTA SEXTA: ni aprobados ni prohibidos; sólo permitidos; deben corregirse.

LISTA SÉPTIMA: peligrosos; prohibidos mientras no sean reformados

LISTA OCTAVA: prohibidos y mandados retirar.

Las listas que agrupan los títulos van por parejas, y mientras la primera de cada serie incluye la calificación básica, la que forma pareja con ella participa de esa misma calificación, con la condición de que los libros se corrijan. Únicamente en los dos últimos casos cambia el criterio, porque los libros de la lista séptima no pueden ser dados de paso con una simple corrección, y necesitan una reforma con profundidad; y los títulos que integran la lista octava resultan absolutamente rechazables, sin paliativos.

La calificación es cauta, gradual, sopesada. El primer doblete de listas constituye los títulos aprobados y recomendados. Al examinar los títulos que aparecen en cada lista parece que no hubiera nada que objetar, acaso porque pasaron el examen satisfactoriamente. Cabe preguntarse qué correcciones había que introducir en la Historia Sagrada escrita por Torre y Marco, o en la que salió de manos de Loriquet, o en la obra de Tovar, Educación cristiana de la juventud. Acaso faltaría alguna frase o apreciación; acaso se pudiera perfilar tal o cual matiz; o se trataba de añadir un detalle para que se pudieran evitar ambigüedades de interpretación. En la lista primera se incluyen los catecismos ya señalados, que resultan aprobados, y en cuya edición el único fallo de Saturnino Calleja es no haber solicitado la previa autorización. Pero se estimaban obras consolidadas, que no precisaban corrección.

Las dos listas, tercera y cuarta, que constituyen la segunda pareja tienen, sobre todo, títulos que tienen que ver con las ciencias, la aritmética, la ortografía o la geometría, es decir, con los saberes escolares elementales 
que los niños estaban aprendiendo en la escuela. La lista tercera es aprobada sin recomendación. Pero ¿necesitaba recomendarse un silabario, un libro de música o de gramática castellana, para que fuera difundido sin problemas de conciencia? Es ahí donde aparece más claramente la mirada estrecha de los criterios del momento, que veía todos los saberes sometidos a la férula de la Iglesia, quien tenía que ejercer la tutela protectora sobre ellos. La corrección que había de ejercerse sobre libros de la cuarta lista, sobre historia, sobre ciencias, sobre la educación escolar, sobre fábulas literarias, o sobre algunos cuentos no creo que fuera tan seria, porque resulta difícil imaginar que aquellos libros publicaran errores históricos de la Iglesia, o apuntaran hacia la aceptación de la evolución, o presentaran los pasajes literarios más escabrosos de la gran cantidad de libros escritos en el pasado. Son posibles sutilezas, carencia de algún matiz, apreciaciones que remataran el sentido pleno de una afirmación,... De otro modo, no se me ocurre pensar qué pudiera faltar o de qué defecto pudieran adolecer semejantes títulos.

Únicamente resultan permitidas, es decir, toleradas, las listas quinta y sexta, que no tienen ni aprobación ni rechazo. Son libros de mero entretenimiento, que no pueden desencadenar ningún mal ni ningún desorden. Parece como si el mero entretenimiento fuera en sí poco deseable, y los censores hubieran preferido que los niños estuvieran siempre ocupados en un aprendizaje permanente que no dejara espacio para la diversión y el ocio; éstos sólo se permiten. Todos los títulos que componen las listas quinta y sexta son cuentos. Se han calificado y agrupado en las anteriores clasificaciones los libros que tuvieran que ver con alguna materia de aprendizaje propiamente dicho. El cuento, el pasatiempo, el entretenimiento no es aprobado ni recomendado; únicamente es permitido. Aparecen títulos conocidos como los dos que se refieren a los viajes de Gulliver, obra de Jonathan Swift, que, sin duda sería una versión abreviada, y privada de la carga ácida y mordaz que tiene en la redacción completa. Aparece el celebérrimo título de La caperucita roja, de Perrault, más otros títulos conocidos, que no tienen nada digno de corrección según el criterio de los censores. La lista sexta es la de los libros que puede ser permitidos, una vez hayan sido corregidos. ¿Qué corrección cabría introducir en el cuento de El pulgarcito? Es el más conocido de los títulos de la lista sexta, aunque no se especifique si se trata del relato de Perrault, o de los Hermanos Grimm. Ninguna de las dos versiones era precisamente edificante desde el punto de vista moral.

Particularmente difícil de abordar es la lista séptima, que mereció a calificación de libros "peligrosos,... mientras no sean convenientemente 
reformados"; por descontado, que mientras eso no suceda queda desterrado su empleo en las escuelas. Títulos ampliamente conocidos son Blanca Nieves, de los hermanos Grimm, La almendrita, o La cenicienta, de Perrault. La gran dificultad para pasar la censura en los libros de esta serie séptima es que en todos ellos aparecen hechizos, encantamientos, conjuros, transformaciones imposibles. Y si esto no sucede en la realidad, y no puede atribuirse una cosa así al poder divino, no queda otra salida que pensar en poderes maléficos o diabólicos, que en modo alguno podían ser tolerados. Hay que decir, sin embargo, en honor a la verdad y en descargo de los censores, que hacen una estimación - una epiqueya - en el sentido de "los que ahora censuramos no recomiendan tales supersticiones ni las enseñan, ni semejantes encantamientos se presentan en forma que los haga algo crébles, sino cual mero entretenimiento y con el rótulo de cuentos. Leer o retener tales frivolidades no es lo que la Sagrada Congregación del Índice considera motivo suficiente para que se tenga a cualquiera por sospechoso de herejía y se proceda contra él". Toman distancia respecto a las verdaderas y auténticas supersticiones y creencias erradas; pero eso no les impide tomar precauciones para no dar pie a que los simples cuentos infantiles, en plan de pasatiempo y diversión, degeneren en falsas creencias rechazadas por la fe. Privados de esa carga maligna, latente, los libros podrán volver a circular una vez hayan sido reformados. Pese a lo cual, la tradición popular ha seguido aceptando que la calabaza se convertía mágicamente en carroza y los ratones se transformaban en elegantes corceles... hasta las doce de la noche. De verdad que no tengo noticias de ningún hereje que lo haya sido como consecuencia de la lectura de La cenicienta.

Finalmente, la lista octava debía ser enteramente proscrita; no admitía reforma alguna. La integran seis títulos. Alguno, por principio, perverso, como Lo que está haciendo el diablo, que no puede ser nada bueno, y es mejor desconocerlo. Otro título es El soldado listo, que no sé si responde al cuentecillo del soldado que, regresando de la guerra, engaña a la posadera para que le haga un "arroz de piedras" que prepara en la cocina con los ingredientes que tenía escondidos, mientras el listillo del soldado aporta unos guijarros que ha tomado del río. Es claro que está mal inducir al engaño. Los otros títulos me resultan desconocidos, salvo El soldadito de plomo, de Hans Christian Andersen. ¿Qué pudieron ver los censores para darle esta categoría? Sin duda, la aberración, antinatural, que supone que una bailarina de papel se enamore locamente de una figura de plomo, en un amor imposible que los empuja a la inmolación compartida. No es aceptable, por más ancha que se tenga la manga. No podía ser dado por bueno algo intrínsecamente perverso. Y fue a parar al último de los escalones, al 
infierno de olvido del que no se sale. Y aunque Saturnino Calleja no lo volviera a editar - lo supongo, pero lo desconozco - otros editores lo hicieron, y lo cierto es que no ha producido tanta perversión antinatural como sospecharon los firmantes del juicio valorativo precedente.

\section{Prioridad de la censura moral}

Lo que aparece muy claro en todo este asunto es que la preocupación de los censores al supervisar y clasificar las obras, y del editor al someterlas a revisión, consiste en velar por la salud moral de los niños, destinatarios directos de los libros. Podría decirse que se trata de una pretensión que no admite el más mínimo reproche. Anteponer la salud moral e intelectual de la infancia era uno de los objetivos expresos proclamados por la Editorial Saturnino Calleja, que lo había concretado en el lema "Todo por la ilustración infantil".

Por tanto, presentar sus libros para que fueran examinados por la comisión correspondiente era un gesto totalmente coherente. Y cuando los miembros designados para dicha comisión emprendieron su tarea no lo hicieron con la voluntad torcida de hacer de los niños personas mal formadas o con criterios retorcidos, sino todo lo contrario, eliminando de su panorama educativo aquello que pudiera resultar nocivo. (Si bien es cierto que los criterios de entonces y de ahora sobre este punto no coinciden).

En consecuencia, movidos por semejantes criterios dejaron completamente a un lado todo lo que pudiera vulnerar los derechos de autor. Porque si en unos casos la recomendación era la de corregir las obras examinadas y en otros la de transformarlas, es patente que lo escrito por el autor real de las mismas quedaba malparado. Pero ése era un asunto trivial, irrelevante. No se trataba de una disputa acerca de un plagio, o de mejorar la calidad literaria de ciertas obras. Y en beneficio de la infancia, todo lo demás podía darse por bueno, aunque se alteraran ciertos escritos.

De hecho, hay indicios más que suficiente como para pensar con fundamento que el asunto de los derechos del autor se trata de una cuestión intrascendente. Por un lado, está el mismo texto del decreto del obispo de Madrid, en el cual se indica, sin más, que se proceda a la revisión y a la reforma de ciertas obras, pero en modo alguno se apunta que hubiera que consultar a los autores literarios para ver si aceptaban los cambios. La única referencia, al final de la revisión o de la renovación es que sean "reformados y aprobados por Nos, previa la oportuna censura". El otro indicio, bastante nítido, es la práctica, habitual en Calleja, de silenciar la 
mayoría de los nombres de los autores: "Su creador no era el mismo Saturnino Calleja, sino anónimos escritores asalariados, de quienes se solía omitir cualquier referencia en los volúmenes"5. Desde este anonimato no casual, es lógico pensar que lo que menos importaba era el criterio del auténtico autor, quien, una vez recibido el precio ajustado por la obra, la ponía enteramente a disposición del editor, sin más control y sin ulteriores reclamaciones. Por otra parte, mal podría reclamar los autores conocidos, pues todos habían muerto para la fecha de 1894.

\section{Los autores mencionados en la censura eclesiástica}

En la relación de títulos, hay algunos que tienen referencia de un autor determinado. Son los menos. La mayoría están incluidos en la práctica comercial de Calleja, y se acogen al anonimato. Son los cuentos los que se encuentran en esta situación, mientras que los otros libros formativos, en la mayor parte de los casos, disponen de nombre de autor.

\section{LiBRos ACEPTADOS}

Astete, Doctrina cristiana (dos ediciones).

Benito, La música para los niños.

Calleja, Geografía (dos ediciones).

Calleja, El pensamiento infantil.

Calleja, Los párvulos.

Calleja, Los párvulos (colección de carteles).

Calleja, Nociones de economía doméstica.

Calleja, Nociones de higiene.

Calleja, Un libro para los niños.

Calleja, Urbanidad para niñas.

Calleja, Urbanidad para niños y niñas.

Chápuli, El muestrario caligráfico.

Escoiquiz, Obligaciones del hombre.

Fenelon, El Padre nuestro.

Fernández, Cartilla para los niños.

Fernández, Definiciones de Aritmética.

5 J. GARCIA PAdRINo, Tradición e innovación en la narrativa infantil, en VARIOS, Estudios de Filología y su Didáctica, II, Madrid, Public. Pablo Montesino - Dep. de Filología y su Didáctica, 1992, 65-82. 
Fernández, Los deberes.

Fernández, Geometría para los niños.

Fleury, Catecismo histórico (dos ediciones).

Fleury, Diálogo de Historia Sagrada.

Flórez González, Lectura de manuscritos.

Gallego, Aritmética para los niños.

Gómez, Gramática castellana.

Gómez, Ortografía castellana.

Granada, La oración del Padre nuestro.

Jiménez Aroca, Catón de los niños.

Jiménez Aroca, Colección de carteles.

Jiménez Aroca, Silabario $1^{\circ}$.

Jiménez Aroca, Silabario $3^{\circ}$.

Jiménez Aroca, Silabario $2^{\circ}$.

Juez, Lecciones de Aritmética.

Miguel Ruiz, Catón de las niñas.

Miguel Ruiz, Colección de carteles.

Miguel Ruiz, Silabario $2^{\circ}$.

Miguel Ruiz, Silabario $1^{\circ}$.

Miguel Ruiz, Silabario $3^{\circ}$.

Miguel y Ruiz, La Buena Juanita.

Ripalda, Doctrina cristiana (dos ediciones).

Ripalda y Fleury.

Rodríguez Navas, Gramática de la lengua castellana.

Rodríguez Navas, Narraciones históricas.

Sabatier, Obligaciones del hombre.

Seijas, Catón metódico de los niños.

\section{LIBROS QUE DEBEN REVISARSE}

Calleja, Historia de España.

Fernández, Trozos literarios en prosa.

Fernández, Trozos literarios en verso.

Fernández y Ruiz, La perla del hogar.

González, Catecismo de Agricultura.

Iriarte, Fábulas literarias.

Jiménez Aroca, Cuentos del abuelo.

Jiménez Aroca, Frases y cuentos.

Loriquet, Historia Sagrada. 
Parravicini, Historia natural para niños.

Parravicini, Tesoro de las escuelas.

Peña, Complemento de la educación escolar.

Rodríguez Navas, Tratado de urbanidad.

Samaniego, Fábulas en verso (dos ediciones).

Torre y Marco, Historia Sagrada.

Tovar, Educación cristiana de la juventud.

Los títulos de la primera lista fueron aprobados en su respectivo grupo, mientras que los de la segunda serie precisaban algún tipo de revisión. Algunos de los autores son suficientemente conocidos como Gaspar Astete, Jerónimo de Ripalda, Claudio Fleury, Luis de Granada, Félix Samaniego, Tomás de Iriarte, Beltrán de Salignac (Marqués de Fenelon), Jean Nicolás Loriquet, Luis Alejandro Parravicini y el propio Saturnino Calleja. Hay una advertencia inevitable que hacer, entre los autores de la segunda serie, porque aparece como obra a corregir la de "Fernández"; pero, consultada la obra, resulta que la selección de los fragmentos que incluye el librito ha sido realizada por "S. C. Fernández", es decir, Saturnino Calleja Fernández. Esto lleva inevitablemente a pensar que el mismo "Fernández", Saturnino Calleja Fernández, es el autor de algunas de las obras que en la columna primera aparecen a su nombre. Otros autores, por el contrario, resultan desconocidos, y quizá su dedicación a la literatura pedagógica, especialmente infantil, no les ha deparado un puesto de relevancia.

A excepción del mismo Saturnino Calleja, quien no podría dificultades para la realización de modificaciones, dada su voluntad positiva y decidida de ir por delante con los libros editados por él, el resto de los autores, al menos los que resultan conocidos, no pondrían pegas, dado que la totalidad había muerto ya para los años en que se llevó a cabo esta revisión. No me es posible decir nada sobre el resto de los autores.

\section{Correcciones previsibles a introducir}

Al carecer de más datos, no resulta fácil suponer qué clase de correcciones habría que introducir en las obras de autores identificados, o en los muchos cuentos anónimos.

Es factible suponer que en los libros de historia se pudiera modificar alguna frase que presentara rasgos poco favorables para la Iglesia, o añadir algún rasgo que acentuara su esplendor o sus aciertos. No creo que las 
correcciones pudieran ir por la vía de introducir a un determinado personaje, puesto que en obras de reducido tamaño, como solían ser siempre las de Calleja, no se podría incluir más que una síntesis, en que forzosamente no podía caber todo lo relativo a la historia de la Iglesia. En el único libro de Historia de España, ocurría otro tanto, no precisamente por la relación histórica en sí misma, sino por lo que tuviera que ver con la Iglesia. Porque el juicio valorativo sobre el mejor o peor acierto de un gobernante, o sobre toda una época, apenas tendría que inquietar a la censura.

En los libros recopilatorios de trozos literarios, como breves antologías, el pensamiento que encerraban sus páginas no era más que responsabilidad de cada uno de los autores presentes en la antología. No tiene lógica pensar que los censores prefirieran la presencia o la ausencia de uno $\mathrm{u}$ otro autor. En todo caso lo que se puede suponer es que se omitiera algún pasaje o estrofa que pudiera generar inquietud en las mentes infantiles.

No se me ocurre ni remotamente por dónde debería discurrir la corrección teológica o moral en el Catecismo de Agricultura, obra de Julián González, cuyo título completo es Catecismo de agricultura para uso de las escuelas de primera enseñanza $a^{6}$. Ni remotamente puedo imaginar qué problemas verían los censores en materias como las semillas, el tiempo de la plantación o de la poda, los esquejes, los injertos, o las plagas que pudieran afectar a cada especie de la huerta.

Las dos Historias Sagradas, las de Jean Nicolás Loriquet, y la de Torres y Marco podría ser sometidas a revisión para modificar algún criterio no muy perfilado en cuanto a la concepción que entonces se tenía de la Historia Sagrada — distante del actual planteamiento como historia de la salvación-. Podría faltar la presencia de algún héroe o campeón de la narración bíblica; podría ocurrir que alguna frase que se pusiera en sus labios no fuera adecuada; o también que se produjera alguna inexactitud cronológica. También podría ocurrir, ahondando más, que estuvieran escritas desde criterios jansenistas y que destilaran estos criterios de forma insinuante, como le había sucedido a la narración o Catecismo Histórico escrito por Fleury; con la diferencia de que éste ya había sido depurado en otros momentos anteriores, y en 1894 no precisó corrección.

6 Tengo referencia de una edición de Calleja, de 1886, anterior en unos años a la intervención del obispado de Madrid-Alcalá. 
La Historia natural para niños, de Parravicini también fue sometida a la labor de pulido. Dudo sinceramente que en un libro de ciencias como éste aparecieran los entonces discutidos y polémicos criterios acerca de la evolución; o que se negara el hecho creador por parte de Dios. Quizá no se ponía de relieve su papel providente. Pero esto no es propio de un libro de ciencias, sino de un tratado religioso.

Y en cuanto al Tratado de urbanidad, de Rodríguez Navas, parece lógico pensar, en sintonía con otros escritos semejantes de la época, que incluyera las normas básicas de urbanidad en el comportamiento en la iglesia, en el respeto a los padres, a los sacerdotes, en la señal de la cruz al salir de casa, en el comportamiento en las procesiones, en evitar toda clase de peligros, malas compañías o lecturas perniciosas. Algunos escritos de esta materia lo hacen así, desde una perspectiva no necesariamente creyente, sino sólo desde el bien hacer y el saber estar. Por eso sólo se me ocurre que faltara alguna de las indicaciones anteriores, o que no estuviera suficientemente resaltada. Y que la corrección fuera por la vía de completar lo que estaba apuntado.

En cualquier caso no son más que suposiciones, pero, a la vista de los tratados y de los temas que incluían los diversos libros que debían ser corregidos, no se me ocurre otra cosa que cavilar sobre las indicaciones precisas que los comisionados hicieron a Saturnino Calleja para que perfilara los libros seleccionados, antes de volver a ponerlos a la venta.

Por otro lado están los cuentos. En ellos el rigor de un tema no constriñe tanto al autor, quien se puede dejar llevar de la imaginación. Los numerosos cuentos anónimos, o de autores conocidos, que fueron sometidos a ajustes, lo tendrían que ser en cosas secundarias. Los que aparecen incluidos en las listas $2^{\mathrm{a}}$ y $4^{\mathrm{a}}$ de la censura madrileña están mezclados con otros tratados, que no son cuentos, y deben ser corregidos. Por otro lado, las listas $6^{\mathrm{a}}$ y $7^{\mathrm{a}}$ están integradas exclusivamente por cuentos; también deben ser corregidos, pero con una clasificación más severa, porque los de la lista $6^{\text {a }}$ sólo son permitidos, en tanto que los de la lista $7^{\text {a }}$ están prohibidos expresamente mientras no sean sometidos a corrección. Los encantamientos, los hechizos, la intervención diabólica libérrima, la capacidad del hombre de adivinar o conocer su futuro por medio de magos o hechiceros... no resultaban compatibles con la fe cristiana. Supongo que es en este punto donde debieron ser revisados antes de volver a ponerlos en circulación. Se eliminarían todos esos aspectos, así como los rasgos gratuitos de crueldad o maldad, el robo y la mentira, el desprecio a lo sagrado o la simple indiferencia. Es posible que ésa fuera la intervención que reclamaba la censura. 


\section{La moralidad de los cuentos en general}

Quiero echar un cuarto a espadas en defensa de los censores. No lo hago desde una postura apologética, para defender a ultranza la intervención de unos eclesiásticos. Menos aún me mueve el prejuicio de que la Iglesia —o sus miembros- nunca se equivoca. Claro que entiendo que es preciso echar un siglo atrás para comprender la mentalidad y los criterios de entonces. Pero sin tener que dar la razón a los censores en este asunto de la intervención sobre el fondo editorial de Saturnino Calleja, no me queda más remedio que decir, con claridad, que la moralidad de los cuentos y de las lecturas infantiles —o las así consideradas de modo tradicional- deja bastante que desear.

Para quien lo dude, me permito sugerir que lea $-\mathrm{o}$ relea- con mentalidad adulta Las aventuras de Robinson Crusoe, de Daniel Defoe. La reflexión amarga, en cierto modo pesimista, la conversión religiosa paulatina de un hombre malvado y descreído, la profunda carga de rechazo de la sociedad, como lugar de perversión, están en el fondo del relato, aunque, a los ojos del niño, predomine la aventura, el naufragio, la lucha por sobrevivir, el rescate de un nativo condenado al sacrificio inhumano, la victoria sobre el resto de los aborígenes, el rescate final. También es posible hacer lo propio con Los Viajes de Gulliver, de Jonathan Swift: su acidez, su ironía no disimulada, la carga de profundidad del hombre utilizado como entretenimiento o como poderosa maquinaria bélica contra el enemigo, aparece por toda la obra; más aún, en las partes no editadas por Calleja, en las que Gulliver arriba a la isla aérea (o Lupata), al país de los banibarbas, de proyectos científicos inverosímiles, o a la sociedad de los caballos (los Houyhnhnms) que desprecian a los estúpidos humanos.

Y esto no es todo. Los cuentos más blancos, más inocentes, suelen incluir en sus versiones íntegras, originales, algunos aspectos que, pensados con calma, ponen los pelos de punta, y llevarían a arrancarlos de las manos infantiles.

El recorrido somero que voy a presentar no tiene desperdicio. Los Hermanos Grimm nos han dejado, entre otros, el cuento de Rapunzels: en él, un matrimonio que desea tener una hija recurre a los malos servicios de

7 Jakob Grimm (1785-1863) y Wilhelm Grimm (1786-1859) eran ambos profesores en la universidad de Göttingen; pasaron a la posteridad por recoger cuentos y narraciones populares en medio de sus ocupaciones universitarias.

8 En el título alemán; en ocasiones se ha traducido al castellano como Rapónchigo, al pie de la letra, es decir, una planta campanulácea. También se ha traducido como Ruiponche, e incluso como Isabel, nombre que resulta más familiar y que en su terminación se parece más al original. 
una hechicera, quien les concede la fertilidad a cambio de que le entreguen la criatura al nacer. Es encerrada en una torre, y cuando crece no tiene otro medio que comunicarse con su amado con la escala que forman sus propios cabellos. También de los Hermanos Grimm es el cuento Hermanito y Hermanita, en el que dos huérfanos huyen de su casa donde son maltratados por la madrastra, que es bruja; ésta les persigue, y convierte al niño en cervatillo. Cuando la niña crece, el rey se casa con ella. La madrastra y su hija continúan la persecución; la matan después de dar a luz, y la hija de la madrastra la suplanta en el lecho real. Pero la madre -rediviva- se aparece por las noches para amamantar a su hijo. Al descubrirse la falsedad, la madrastra es ejecutada en la hoguera, su hija es devorada por animales salvajes, la madre difunta resucita y su hermano hechizado recupera su condición de persona.

No es lo más grave en punto a inmoralidad (desde la perspectiva adulta), pues también los Hermanos Grimm escribieron Toda-clase-de-pieles (en alemán, Allepelze), que ha sido traducido al castellano como Piel de Asno, relato en el que muere la reina, y el rey pretende nada menos que casarse con su propia hija, que es el vivo retrato de su madre muerta; la chica huye, horrorizada, para tratar de evitar semejante suerte, pero al final, el rey consigue su propósito y se casa con su hija. Así, como suena. En El Enano Saltarín, igualmente de los Hermanos Grimm, este diablejo hace hilar a una doncella paja, que se convierte en hilos de oro; de esta manera se casa con el rey, pero con la promesa de que entregue al Enano a su hijo una vez que se haya casado y sea reina. Igualmente es obra de los Hermanos Grimm el cuento Hänsel y Gretel (o Hans und Gretel), en el que unos padres extraordinariamente pobres, que no pueden alimentar a sus hijos, toman la decisión de abandonar a su suerte a los niños en el bosque. También es obra de los Hermanos Grimm una de las narraciones tituladas Pulgarcito; en este relato, el padre vende a su hijo por una pieza de oro a dos forasteros que, asombrados de su diminuto tamaño, piensan sacar partido de aquel prodigio. El propio niño insiste a su padre en que lleve a cabo la venta. Y, ya propiedad de los feriantes, comete toda clase de tropelías y engaños para dejarlos y regresar a su casa.

Charles Perrault (1628-1703), literato, miembro de la Academia Francesa, fue también autor de varios cuentos que le proporcionaron fama. Entre ellos está uno titulado también Pulgarcito. Fue, sin duda, el punto de partida de la narración paralela de los Grimm. En el cuento de Perrault, unos padres míseros han decidido abandonar a sus siete hijos (como sucedía en Hans und Gretel) al no poder alimentarlos; como el ingenio de Pulgarcito permite que los niños abandonados retornen a casa, -reinciden- 
tes - los abandonan por segunda vez; entonces acuden a casa de un ogro, quien está dispuesto a comerse a los niños; pero Pulgarcito quita a las hijas del ogro las coronas con las que duermen y las pone en las cabezas de sus hermanos y la suya propia; de esta forma, el ogro mata a sus propias hijas. No contento con el crimen, Pulgarcito se sirve de toda clase de engaños para arrebatar al ogro todas sus posesiones.

No terminan ahí las inmoralidades y licencias de los cuentos infantiles. Es suficientemente conocido el relato de Charles Perrault, Barba Azul, enamoradísimo de su esposa, hasta que la manda a hacer compañía con las anteriores mujeres, cuyos cadáveres guardaba encerrados bajo llave en una cámara secreta de su palacio. Giovanni Francesco Straparola (1495-1577), novelista y poeta, escribió La muchacha en el arcón; en este cuento, Teobaldo, rey de Salerno, enviuda, y decide casarse con aquella mujer a la que encaje a la perfección el anillo de su difunta esposa; son desechadas multitud de aspirantes, hasta que un día, por casualidad, su hija se prueba el anillo que le corresponde con total justeza; Teobaldo, sin más, piensa en casarse con su propia hija Doralisa, a pesar de las advertencias que le llegan por todos lados. También es obra de Straparola el relato titulado Scarpafico, labrador que es objeto de un timo por parte de tres personas; en la más pura venganza, les tima a los aprovechados; más aún, les indujo a que mataran a sus respectivas mujeres. Entonces éstos trataron de vengarse a su vez, y dieron muerte no a Scarpafico, sino a un pastor al que, con engaño, el protagonista indujo a que ocupara su lugar; finalmente, siguiendo la cadena de engaños, consiguió matar a los tres. Muy edificante, sin duda.

Alexander N. Afanasiev (1826-1871), literato y novelista, recogió cuentos del folklore ruso, así como del finlandés. En el titulado El juicio de Shemiaka, un juez corrupto y prevaricador dicta por tres veces sentencia injusta, presionado por las amenazas de muerte del protagonista. En la segunda de las sentencias, como Shemiaka ha provocado la muerte del hijo de un campesino al caer sobre el niño, la sentencia consiste en que cohabite con la mujer del campesino hasta que ésta tenga otro hijo, que sustituya al que perdió. Jeanne Marie Leprince de Beaumont (1711-1780), conocida también como Madame Leprince de Beaumont, redactó La bella y la bestia; en el relato, una bestia despreciable -luego se convertirá en príncipe esbelto y joven- perdona la vida a un mercader con la condición de que una de sus tres hijas debe ofrecer voluntariamente su vida para salvar la de su padre.

A la vista de todo lo que precede, nada tiene de particular que el danés Hans Christian Andersen (1805-1875) escribiera El soldadito de plomo, que, comparado con la serie de atrocidades e inmoralidades referidas, es pura minucia, a pesar de que la censura eclesiástica madrileña lo tuvo por 
un relato irrecuperable (junto con otros no conocidos), sin posibilidad de enmienda, transformación o corrección. La recopilación incluye incestos, robos, asesinatos, jueces prevaricadores, engaños, venganzas, padres que abandonan a sus hijos, o los entregan a la hora del nacimiento, o los venden por unas monedas, parricidios, adulterios, amenazas,... Todo un repertorio del más depurado estilo educativo, destinado a ser propuesto a las mentes de los niños en sus narraciones favoritas.

Pero son muchos más, y la lista sería larguísima, los cuentos en que aparecen engaños, venganzas, mentiras, muertes, robos, anomalías sexuales, agresiones,... Es decir, todo un catálogo de comportamientos a los que la educación de los niños recurre unas veces para proponerlos como objeto de rechazo, pero en no raras ocasiones como medios normales para conseguir lo que se pretende. Si a ello añadimos la presencia de diablos, ogros, brujas, hechiceras y encantadores con toda la caterva de pócimas, filtros, conjuros y encantamientos, tenemos servida una especie de carta de inmoralidades y anomalías para ser servida a las mentes infantiles.

No propongo todo lo anterior para justificar la intervención censora del obispado de Madrid en 1894. Lo hicieron con arreglo a los criterios que les parecieron oportunos para llevar a cabo su labor. Pero no es menos cierto que la literatura infantil de los cuentos, dejando volar la imaginación, y con unos criterios amplios, que los niños captan a su manera, ha ofrecido y continúa haciéndolo, unas normas morales que no son precisamente las más edificantes. Una vez que termina el relato - leído o narrado- nadie en su sano juicio educa a un niño proponiéndole que lleve a cabo un programa de actuación como el que ha aparecido. Pero el cuento es el cuento, y en él, la fantasía, la imaginación, y el situarse fuera y por encima del mundo real deja abierta toda una serie de permisiones que, en otras circunstancias serían poco recomendables.

Parece que esto también lo tuvieron en cuenta los censores madrileños cuando afirmaron en su informe que se trataba únicamente de "cuentos". A pesar de lo cual, procedieron con cierto rigor en su valoración, depurando criterios y formas no aceptables. Es una verdadera lástima no poder disponer de algunas de esas narraciones antes y después de las correcciones señaladas, para haber podido llevar a cabo un cotejo en aquellos puntoś que fueron objeto de reforma.

En cualquier caso, ahí están los datos que evidencian un episodio escasamente conocido en torno a los célebres cuentos de Calleja. Y ahí está la advertencia de que en el lugar más inocente y menos previsible puede estar agazapado el mal y el error. Advertencia que nos debe hacer cautos a la hora de contar cuentos a los niños. 


\section{APÉNDICE DE TODOS LOS LIBROS CITADOS, EN ORDEN NUMÉRICO:}

\section{LISTA PRIMERA: aprobados y recomendados}

1. Miguel y Ruiz, "La Buena Juanita”.- 2. Calleja, “Los párvulos”.- 3. Calleja, (colección de carteles), "Los párvulos".- 4. Fleury, "Catecismo histórico" (dos ediciones).- 5. Ripalda y Fleury.- 6. Astete, "Doctrina cristiana" (dos ediciones).- 7. Ripalda, "Doctrina cristiana" (dos ediciones).- 8. Fleury, "Diálogo de Historia Sagrada".- 9. Calleja, "Un libro para los niños".- 10. Sabatier, "Obligaciones del hombre".- 11. Escoiquiz, "Obligaciones del hombre".- 12. Fenelon, "El Padre nuestro".- 13. Calleja, "Urbanidad para niñas".- 14. Calleja, "Urbanidad para niños y niñas".- 15. Fernández, "Los deberes".- 16. Granada, "La oración del Padre nuestro".- 17. La niña caritativa, El legado de un padre.- 18. La madrastra.- 19. El pastor de las liebres.- 20. La flor marchita.- 21. El hijo obediente.- 22. Fe, Esperanza y Caridad.- 23. En guerra con el mar.24. La caja de cerillas. - 25. La conciencia.- 26. Blanca, la huerfanita.-27. El caballero Bayardo.- 28. Rivadeneyra, "Vida de la Virgen".- 29. El camino del cielo.- 30. El bergantín.-31. La Nochebuena.

\section{LISTA SEGUNDA: aprobados y recomendados; deben corregirse}

32. Jiménez Aroca, "Frases y cuentos".- 33. Jiménez Aroca, "Cuentos del abuelo".- 34. Torre y Marco, "Historia Sagrada".- 35. Loriquet, "Historia Sagrada".- 36. Tovar, "Educación cristiana de la juventud”.- 37. El arte de ser feliz.- 38. La comadre muerta.- 39. La Religión Católica.- 40. El perdón de una culpa.- 41. Proteger a las golondrinas.- 42. Belleza y modestia. - 43. El tesoro engañoso. - 44. La herencia.- 45. La ingratitud.46. El médico ambicioso.- 47. La rana encantada.- 48. Santificar las fiestas. 49. El castigo merecido.

\section{LISTA TERCERA: aprobados sin recomendación}

50. Jiménez Aroca, "Catón de los niños".- 51. Jiménez Aroca, "Silabario

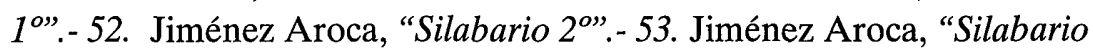


3".- 54. Jiménez Aroca, "Colección de carteles".- 55. Miguel Ruiz, "Catón de las niñas".- 56. Miguel Ruiz, "Silabario 10".- 57. Miguel Ruiz, "Silabario 20".- 58. Miguel Ruiz, "Silabario 3o".- 59. Miguel Ruiz, "Colección de carteles".- 60. Fernández, "Cartilla para los niños".- 61. Seijas, "Catón metódico de los niños".- 62. Rodríguez Navas, "Narraciones históricas".- 63. Flórez González, "Lectura de manuscritos".- 64. Benito, "La música para los niños".- 65. Calleja, "Geografia" (dos ediciones).- 66. Gómez, "Gramática castellana".- 67. Rodríguez Navas, "Gramática de la lengua castellana".- 68. Calleja, "El pensamiento infantil".- 69. Juez, "Lecciones de Aritmética".- 70. Fernández, "Definiciones de Aritmética".- 71. Gallego, "Aritmética para los niños".- 72. Fernández, "Geometría para los niños".- 73. Gómez, "Ortografía castellana".- 74. Calleja, "Nociones de higiene".- 75. Calleja, "Nociones de economía doméstica".- 76. Chápuli, "El muestrario caligráfico".- 77. Ejercicio preliminar de lectura.- 78. La física al alcance de los niños. 79. Geografia histórica.- 80. El mar y sus misterios. - 81. Geografía astronómica.- 82. Reino vegetal.- 83. Reptiles y peces.- 84. El brujo y las tres hermanas.- 85. Pepito y Mariquita.- 86. No seáis mentirosos.- 87. El premio y el castigo.- 88. Jorge el valeroso.- 89. Roberto y Cecilia.- 90. El hombre en la luna.- 91. El espejo de Luisita.- 92. El gato perezoso.- 93. Las riquezas del sabio.- 94. La casa de Tócame Roque.- 95. Un rasgo de amor filial.- 96. La mentira más grande.- 97. La leyenda de la seda.- 98. La senda de la fortuna.- 99. El rey Tragabuches.- 100. El barril de aceitunas.- 101. El ciego por su culpa.- 102. El príncipe narigudo.- 103. El rey Midas.- 104. Al calor de una cerilla.- 105. Los dos gemelos.- 106. El lenguaje de las bestias. 107. Dios en todas partes.- 108. Debemos estar agradecidos.- 109. La tía miserias.- 110. La flor del lino.- 111. El solitario.- 112. Los tres ciegos. - 113. Las dos rocas.- 114. Una nariz prominente.- 115. Un viaje a la mesa.- 116. El ministro envidioso.- 117. El joven naturalista.

\section{LISTA CUARTA: aprobados sin recomendación; deben corregirse}

118. Rodríguez Navas, "Tratado de urbanidad".- 119. González, "Catecismo de Agricultura".- 120. Parravicini, "Historia natural para niños".121. Peña, "Complemento de la educación escolar".- 122.- Fernández, "Trozos literarios en prosa".- 123. Fernández, "Trozos literarios en verso".- 124. Calleja, "Historia de España".- 125. Parravicini, "Tesoro de las escuelas".- 126. Iriarte, "Fábulas literarias".- 127. Samaniego, "Fábulas en verso" (dos ediciones).- 128. Fernández y Ruiz, "La perla 
del hogar”. - 129. Viaje alrededor del mundo.- 130. Historia de las bellas artes. - 131. Los tres reinos de la naturaleza.-132. La civilización y los grandes inventos. - 133. La medalla de la Virgen.- 134. El peral misterioso.- 135. Recuerdos históricos. - 136. Las aves. - 137. Los mamíferos.138. La princesa fregona.- 139. La hermanita de los pobres.- 140. El ermitaño.- 141. El regalo de la hada.

\section{LISTA QUINTA: ni aprobados ni prohibidos; sólo permitidos}

142. El violín mágico.- 143. Los cabritos y el lobo.-144. El doctor que todo lo sabe.- 145. Juana la lista.- 146. Lo que puede la astucia.- 147. Un amigo generoso.- 148. Los pájaros injuriados. - 149. Los músicos improvisados.- 150. Quién de los dos corre más.- 151. Los tres convidados.152. La cruz del diablo.- 153. Las agudezas de Juan.- 154. Viaje de Gulliver al país de los gigantes. - 155. Viaje de Gulliver al país de los enanos. - 156. La soledad y el olvido.- 157. El jorobado.- 158. La fortuna y la desgracia.- 159. Un banquete extraño.- 160. La fama del embustero.161. El castigo de un bribón.- 162. El gallo listo.- 163. Soñar despierto.164. El cantor del bosque.- 165. La caperucita roja.- 166. Aventuras del Barón de la Castaña.- 167. Las tres plumas.- 168. El flautista valiente.169. María Pez y María Oro.- 170. La joven hermosa novia.- 171. Aventuras de un náufrago.- 172. La gallinita y el pollito.- 173. Nobleza de un artesano.- 174. Justicia de Dios. - 175. Viajes en globo.- 176. La danza de las flores.- 177. El herrero jactancioso.- 178. El traje invisible.- 179. El gatito y las agujas. - 180. Un convite original-. 181. Las ranas mágicas.182. El fiel Juan.

\section{LISTA SEXTA: ni aprobados ni prohibidos; sólo permitidos; deben corregirse}

183- El pulgarcito.- 184. La fuente de oro.- 185. Aquí no hay tal desgracia.186. El negrito y la pastora.- 187. Nicolasón y Nicolasillo.- 188. La reina de las hormigas. - 189. El caballo artificial.-190. La mitología griega y romana.- 191. Cuentos de Fernandillo.- 192. El baúl maravilloso.- 193. El niño juez.- 194. El príncipe Balsora.- 195. El carbón de oro.- 196. El poder de la fortuna.- 197. Manuel.

\section{LISTA SÉPTIMA: peligrosos; prohibidos mientras no sean reformados}

198. El ramito de nogal.- 199. Barba azul.- 200. Un joven afortunado.- 201. Un sueño largo.- 202. La hija del molinero.- 203. La princesa de Tonkin.- 204. La montaña de cristal.- 205. Rosita y Joaquinito.- 206. Los tres 
hermanos. - 207. La nevadita.- 208. La hermosa en el palacio encantado.- 209. La cenicienta.- 210. La montaña de imán.- 211. El palacio subterráneo.- 212. El príncipe mono.-'213. La cierva encantada.- 214. Los perros negros. - 215. El médico y el rey.-216. El castillo encantado.- 217. El pescador.- 218. El collar de diamantes. -219. Blanca Nieves.- 220. El premio de Luisito. -221. La princesa de los cabellos de oro.-222. Rafaelito.- 223. Aventuras de dos niños.- 224. Las hijas del leñador.- 225. La princesa Isabel. - 226. El enano encantador.- 227. La estatua prodigiosa.228. La fragua encantada.- 229. La almendrita.- 230. Los príncipes encantados. - 231. El premio de la virtud.- 232. El alcázar de la dicha.233. Los sobresaltos de un sastre.- 234. Historia de un rey tuerto. - 235. La cabrita de oro.- 236. Las aventuras del feísimo Lentejilla.- 237. El viejo hechicero. - 238. El cantarito de lágrimas. - 239. El silbato prodigioso.- 240. El príncipe penitente.- 241. El diablo burlado.- 242. La ramita de mejorana.- 243. El castigo de un ambicioso.- 244. Aventuras de Rogelio -245. La buena pesca.- 246. La vaca y el ternero.- 247. La estatua de mármol.- 248. La armadura misteriosa.- 249. Dos hermanas envidiosas.250. Un novio encantado. - 251. La cola del gato.- 252. El oro del bosque.- 253. El caballero sin nombre.- 254. El castillo de cartón.- 255. Las tres hilanderas. - 256. La bola de oro.- 257. Un amigo de los niños.- 258. El anciano solitario.- 259. Un cuento chino.- 260. El premio de una buena acción.

\section{LISTA OCTAVA: prohibidos y mandados retirar}

261. Lo que está haciendo el diablo.- 262. El soldado listo.-263. El príncipe y la ondina.- 264. Rafael.- 265. El príncipe Simplicio.- 266. El soldadito de plomo. 